\title{
Aisthesis
}

Firenze University Press www.fupress.com/aisthesis

OPEN ACCESS

Citation: D. Alvargonzález (2021) The idea of substantive arts. Aisthesis 14(1): 135-151. doi: 10.36253/Aisthesis-11912

Copyright:@2021D.Alvargonzález. This is an open access, peer-reviewed article published by Firenze University Press (http://www.fupress.com/aisthesis) and distributed under the terms of the Creative Commons Attribution License, which permits unrestricted use, distribution, and reproduction in any medium, provided the original author and source are credited.

Data Availability Statement: All relevant data are within the paper and its Supporting Information files.

Competing Interests: The authors have declared that no competing interests exist.

\section{The idea of substantive arts}

\author{
David Alvargonzález \\ University of Oviedo (Spain) \\ dalvar@uniovi.es
}

\begin{abstract}
The Spanish philosopher Gustavo Bueno coined the expression "substantive arts" to refer to those arts that do not serve any immediate, mundane or practical purpose. In this paper, I briefly present this idea and put forward a definition of the substantive arts as an alternative to those used until now. Starting from the assumption that since the end of the 18th century there has been a set of arts that have their own substantivity, I expound on certain criteria widely used as distinctive features to define the substantive arts. I subsequently put forward an alternative intensional criterion to characterize the substantive arts. To end, I draw some corollaries following from the application of this criterion.
\end{abstract}

Keywords: fine arts, definition, substantive arts, distinctive features.

\section{INTRODUCTION}

In this paper, I make the supposition that the idea of substantive arts emerged at the end of the 18th century and in the first half of the 19th century to designate arts that ceased to serve practical worldly interests external to them. Having reached their own autonomy, they apparently would have no other meaning than the aesthetic enjoyment of their own content. Such art has been called fine art, noble art, pure art, useless art, aesthetic art, contemplative art and superfluous art. I prefer "substantive arts", coined by the Spanish philosopher Gustavo Bueno (Bueno [2000a]), since it best reflects the fact that these arts no longer conceive of themselves as servants of some other cultural institution - thus ceasing to be deemed as adjective arts - but are self-understood as endowed with their own substantivity.

In the first section, I take up Paul Oskar Kristeller's thesis that the emancipation of these arts came at the end of a long historical process that did not culminate until the 18th century (Kristeller [1951], [1952]). The arts began as adjective arts serving the pur- 
poses of religion, politics, the army, the interests of specific social classes, morality and entertainment, and were gradually emancipated from these adjective functions. Theories of art in antiquity, the Middle Ages and the Renaissance sought to understand the arts in historical moments insofar as they were adjectives serving other institutions, but they ceased to be applicable once emancipated, since their autonomy enabled expansion in unforeseen directions. I will comment briefly on some of the most influential theories in the arts that have been put forward to account for the new reality of the substantive arts. This review does not intend to make a detailed critique of all such theories, but simply to place my definition within the context of the others.

The second section lays out an alternative proposal that starts by recognizing that an intensional definition of the arts is possible. While extensional definitions list everything falling under the definition by enumerating the extension of the set, intensional definitions specify the necessary and sufficient conditions to fall under such definition by indicating the internal content of the defined concept. The set $\mathrm{A}=(1,3,5,7,9)$ can be defined either by listing the items (extensionally) or by giving its distinctive characteristic (intensionally): "odd natural numbers less than ten". In this paper, I hold that the substantive arts are a species within the genus of techniques that have certain special distinctive characteristics. Contrary to formalist theories, I argue that artwork and art performances can never achieve total disconnection from other parts of the world and that the purpose of the substantive arts is not autonomous or selfreferential, but depends on that connection with the world external to the arts. This connection is first genetic and then structural since it supposes that there is a more or less close analogy between works of art and these other parts of the world. If so, based on the theory of analogy proposed by David Alvargonzález, the substantive arts fulfill the two functions typical of analogies: to analyze this analogous world and to explore ways to extend and vary it freely (Alvargonzález [2020]).
In the third section, I draw certain corollaries following the proposed criteria to characterize the substantive arts.

\section{THE IDEA OF SUBSTANTIVE ARTS}

Paul Oskar Kristeller argued that the fine arts are recent in origin, which he located in $18^{\text {th }}$-century Western Europe (Kristeller [1951], [1952]). As his thesis goes, in classical antiquity and the Middle Ages the aesthetic qualities of artworks were not separated from other practical functions typical of the techniques also sustaining that the artworks that today we place within the group of fine arts were dispersed and classified in highly heterogeneous groups. Poetry, grammar and rhetoric appeared together, whereas music was always accompanied by mathematics and astronomy and the visual arts were considered purely technical and artisanal: painters were associated with pharmacists, sculptors with goldsmiths and architects with masons and carpenters. In the Renaissance, the visual arts were linked with geometry, perspective and anatomy, and were championed so that painters, sculptors and architects could be emancipated from artisans and grouped into what Vasari called arti del disegno. The development of modern sciences in the 17th and 18th centuries led to a progressive separation of the sciences (geometry, optics, astronomy) from the arts, paving the way for the appearance of the modern preRomantic system of the arts, such as Batteux's five fine arts (1746): music, poetry, painting, sculpture and dance. For Batteux, architecture and eloquence were "mixed arts" since they pursue both utility and aesthetic pleasure (Kristeller [1951], [1952]).

According to Wilcox and Murphy, in the early $19^{\text {th }}$ century Benjamin Constant, Victor Cousin and Théophile Gautier first used the formula of "art for art's sake", albeit with different meanings, contending that the arts have no other purpose than their very own cultivation and that all purposes pervert art (Wilcox [1953]; Murphy [2018]). 
The arts were defined as an end in themselves, as "pure art", as the free, independent, autonomous construction of specific works, as superfluous, non-useful, non-utilitarian, contemplative arts removed from the contingencies of everyday life. In my view, as introduced by the Spanish philosopher Gustavo Bueno (Bueno [2000a]), the label "substantive arts" has the advantage of focusing on the difference between the arts understood as serving other institutions and pursuing practical purposes external to them ("adjective arts") and the arts self-conceived as sovereign, independent, autonomous and therefore endowed with their own substantivity. My preference for the label "substantive arts" rests on the drawbacks carried by other alternative denominations. These substantive arts do not always embody the value of beauty (they are not, therefore, "fine arts") and may be neutral from an aesthetic point of view (they are not, therefore, always "aesthetic arts"). Their usefulness can only be evaluated ex post facto, with which they are not adequately coined as "useless", "contemplative" or "superfluous" arts. Nor are they activities to be characterized as more "noble" or "purer" than others.

1.1. Limitations of classical and medieval aesthetic theories when characterizing the substantive arts

During the long period in which the arts fulfilled adjective functions, there were fundamentally three philosophies accompanying them:

1. The idea of the arts as bearers of positive aesthetic values: beauty, grace, serenity, pleasure, intensity, balance, virtuosity. This theory was defended by Plato, Alberti, and Moses Mendelssohn.

2. The conception of the arts as an imitation of nature. This theory was formulated by Aristotle and by Leonardo da Vinci. At the same time as the emancipation of what he called "fine arts" began, Batteux defined art as the imitation of nature selecting the beautiful (Batteux [1746])

3. The metaphysical conceptions that the arts reflected specific attributes of God (Summa Theologica I, q.5).
The expansion of the substantive arts invalidated the classical ideas used to characterize the adjective arts as a way to understand the now emancipated arts. Characterizing substantive works of art as bearers of positive aesthetic values (what we could call the "aestheticist" theory of art) ceased to be effective for three reasons. Firstly, because aesthetic values, especially beauty, are also present in many artifacts and performances of human etiology having immediate practical utility. Aesthetic values do not then serve as a distinctive feature of the substantive arts since the deliberate search for aesthetic values can occur in both substantive and servile works of art. Secondly, because aesthetic values also appear as predicated aesthetic values (not constructed or acted upon), insofar as we predicate them on the works of nature which, however, are not works of substantive art. Thirdly, in some cases the newly emancipated substantive arts claimed to cultivate negative aesthetic values (deformed, disproportionate, gloomy, grotesque, dirty, disgusting, rude, clumsy, vulgar, imperfect and incomplete, to cite but a few), as Karl Rosenkranz (1853) studied in Aesthetics of Ugliness. On the other hand, the existence of artworks with neutral aesthetic values must also be taken into account: Marcel Duchamp considered readymades to be appearances being beyond good and bad taste.

As "mimicry" or "naturalism", the theory of art as an imitation or recreation of nature also reached its limits when it came to the new substantive arts once they entered the field of abstract art and tried to cut off any reference to the ordinary figurative world (Osborne [1979]). Futurism, surrealism, Dadaism, minimalism and conceptualism are ways of making art that test the classical doctrine of imitation.

With their emphasis on the participation of specific divine attributes (beauty, truth, goodness), the metaphysical theories about art found their raison d'être in times when the arts were adjectives of religion, but they fell from grace once the arts were emancipated from those liturgical functions and from such a transcendent genesis. 
Agnostics, atheists, materialists, positivists and nihilists rejected such metaphysical theories since they did not need transcendent hypotheses to justify the existence of the arts.

\subsection{A brief consideration of theories about art following the constitution of the substantive arts}

The arts' emancipation from their earlier adjective functions generated new proposals which sought to characterize this new group of fine arts, now understood as substantive, autonomous and removed from any practical purpose beyond the cultivation of art itself.

While not exhaustively, I will briefly refer to certain theories that deal with the definition of what I call substantive arts. Table 1 includes eight situations. The first two deal with those that deny the existence of substantive arts (1) and those that affirm their existence but deny the possibility of defining them (2). Positions (3-6) put forward various criteria to define them (historical, subjective, aesthetic, formal, metaphysical). To end, position (7) includes specific disjunctive definitions and position (8) accounts for definitional pluralism, defending that there are different definitions for various contexts. The purpose of this classification is not to make an exhaustive analysis of such theories, but rather to place the theory advanced in the second section within a dialectical context to make it intelligible.

\section{A. Evolutionism and functionalism}

Evolutionary theories argue that the arts arose in the Paleolithic as a consequence of the biological evolution leading to the appearance of

Table 1. Definitions of substantive arts.

\begin{tabular}{|c|c|c|c|}
\hline type of definition & $\begin{array}{l}\text { identification label of the } \\
\text { theory }\end{array}$ & core thesis & authors \\
\hline $\begin{array}{l}\text { A. There is no } \\
\text { substantive arts }\end{array}$ & $\begin{array}{l}\text { Evolutionism } \\
\text { Cultural and social } \\
\text { functionalism }\end{array}$ & $\begin{array}{l}\text { All the arts are adjectives and fulfill adaptive, } \\
\text { cultural or ideological functions }\end{array}$ & $\begin{array}{l}\text { Dissanayake Miller } \\
\text { Eibl-Eibesfeldt } \\
\text { Mattick } \\
\text { Clowney }\end{array}$ \\
\hline $\begin{array}{l}\text { B. Definition is not } \\
\text { possible }\end{array}$ & Skepticism & $\begin{array}{l}\text { We know how to use the word "art" in } \\
\text { certain contexts }\end{array}$ & $\begin{array}{c}\text { Ziff } \\
\text { Weitz } \\
\text { Goodman }\end{array}$ \\
\hline $\begin{array}{l}\text { C. Extensional } \\
\text { definition }\end{array}$ & Institutionalism & $\begin{array}{l}\text { Historical definition: connection with } \\
\text { previous arts } \\
\text { Institutional definition: group of experts }\end{array}$ & $\begin{array}{c}\text { Levinson } \\
\text { Carney } \\
\text { Dickie } \\
\text { Fokt } \\
\text { Danto }\end{array}$ \\
\hline $\begin{array}{l}\text { D. Intensional, } \\
\text { subjetual definition }\end{array}$ & $\begin{array}{l}\text { Expressivism } \\
\text { Experiencism }\end{array}$ & $\begin{array}{c}\text { Author's expression } \\
\text { Author's intention } \\
\text { Spectator's aesthetic experience }\end{array}$ & $\begin{array}{c}\text { Tolstoi } \\
\text { Ducasse } \\
\text { Collingwood } \\
\text { Croce } \\
\text { Beardsley }\end{array}$ \\
\hline $\begin{array}{l}\text { E. Intensional, formal } \\
\text { definition }\end{array}$ & Formalism & $\begin{array}{l}\text { Exclusive consideration of pure aesthetic } \\
\text { forms }\end{array}$ & $\begin{array}{l}\text { Hanslick, } \\
\text { Bell, Greenberg, } \\
\text { Zamoyski }\end{array}$ \\
\hline $\begin{array}{l}\text { F. Intensional, } \\
\text { trascendent definition }\end{array}$ & Metaphysical theories & $\begin{array}{l}\text { The realization of freedom } \\
\text { The apprehension of noumenon } \\
\text { The phases of the dialectic of the spirit } \\
\text { Art as "bringing-into-being" }\end{array}$ & $\begin{array}{c}\text { Novalis } \\
\text { Schopenhauer Schiller } \\
\text { Hegel } \\
\text { Heidegger } \\
\text { Souriau }\end{array}$ \\
\hline $\begin{array}{l}\text { G. Disjunctive } \\
\text { definition }\end{array}$ & Cluster theories & C v D v E v ... & $\begin{array}{c}\text { Tatarkiewicz, Gaut, Andreev \& Kuznetsova } \\
\text { Davies }\end{array}$ \\
\hline $\begin{array}{l}\text { H. Definitional } \\
\text { pluralism }\end{array}$ & Contextualism & A different definition for each context & Uidhir \& Magnus \\
\hline
\end{tabular}


Homo sapiens. Since all cultures have practices and products that we recognize as artistic, evolutionists infer that aesthetic preferences, interests and capacities are innate and result from natural and sexual selection (Dissanayake [1992]; Miller [2000]: 258-92).

Functionalist theories of art share the common objective of determining the function of the arts in each society, culture and historical moment so as to explain their origin and their persistence. Ethological and ethnological functionalism studied the role of arts in the prestate societies of our primitive contemporaries: Irenaus Eibl-Eibesfeldt argued that the artistic components of those cultures serve to enhance myths, legends, beliefs and rituals (Eibl-Eibesfeldt [1988]). When applied to historical societies, functionalist theories connect the arts to social, political and economic factors. According to Paul Mattick, the institution of the autonomous fine arts typical of Western societies in the last two centuries has a social function as well: museums and concert halls are the reliquaries where these societies keep the material performances of their higher self (Mattick [2003]: 133). For Clowney, the autonomous fine arts fulfill a purely ideological function consisting of differentiating the domain of the "intellectual" along with law, morality and philosophy - from the productive forces of ordinary everyday life (Clowney [2011]: 316).

Evolutionism and functionalism are relevant insofar as they gain an understanding of the external purposes of the arts in their adjective function, as they study pre-state societies and the uses of the arts prior to the $19^{\text {th }}$-century in Europe. Their understanding of modern arts assumes that their unity or similarity is limited to their merely adjective function at the service of the sexual selection or the ideology of specific elites, whilst undervaluing the production processes of ordinary consumer goods. On the contrary, without denying the adjective origin of the arts, in this paper I defend the existence of substantive arts.

\section{B. Skepticism}

Paul Ziff contended that we must renounce a definition of art as a set of characteristics that provides a suite of adequate conditions and settle for reference to some paradigmatic or characteristic "clear cases" of what is considered a "work of art". Ziff highlights the differences between the various arts, especially between poetry and the visual arts, arguing that the uses of the expression "work of art" are changing, especially in the times of artistic revolutions, and no aesthetician is an oracle capable of anticipating the future of art. Furthermore, such uses, like so many others, depend on the context in which the expression "work of art" is determined. He concludes that no definition can ever account for all these heterogeneous uses (Ziff [1953]).

Morris Weitz argued that the question «What is the nature of art?» cannot be defined in any manner since a definition of art is logically impossible. Taking cues from Wittgenstein, Weitz concluded that there is no set of common properties of art, but only a number of similarities, since "art" is an open concept and its conditions of application are amendable and correctable. Art is subject to changes, expansions, novel creations, innovations and originalities. Only in logic and mathematics is it possible to establish the conditions necessary for the application of a concept (Weitz [1956]). The analytic philosopher Nelson Goodman also formulated an anti-essentialist claim with respect to art. Ordinary knowledge, sciences and the arts are systems of symbols contributing to understanding the world and requiring interpretation in line with various syntactic and semantic rules (Goodman [1968]; Goodman and Elgin [1988]). His attempt to specify the "symptoms of the aesthetic" is not distinctive since he recognizes that a work of art can occur in which these "symptoms" do not appear (Goodman [1978]: 67-68). Contrary to this position, in this article I defend that it is possible to propose an intensional definition of the substantive arts.

\section{Historicism}

From a historicist perspective, Jerrold Levinson also recognized that modern art has no spe- 
cific purpose and «is purely historically constituted practice» (Levinson [1993]: 414). Historicist positions argue that the only way to characterize art is through its connection with other artwork of the past (Levinson [1979], [1989], [1993], [2002]; Carroll [1988], [1997], Stecker [1990], [2000]). James Carney advocates for a historicism centered on the study of the various styles so as to understand the causal influence of the past on the present (Carney [1994]: 114).

Stephen Davies calls this recursive way of defining substantive art the "cladistic theory of art» due to the resemblance to cladistic theories of biological species (Davies [2012]: 379) and advocates for its utility, while still recognizing that this type of theory is indeed incomplete as a definition of art (Davies [1997], [2004], [2010], [2015]).

A theory adjacent to this historicist approach is the theory of art as a cultural institution. Once it has been established that the present-day fine arts have no clear purpose, the only practical way to know what art is would be by reference to what an authorized elite or some culturally competent person labels, dubs and honors as art. Applying this criterion, Duchamp's readymades and Warhol's Brillo Boxes clearly qualify as art. (Dickie [1974]; Fokt [2014], [2017]). In this vein, Arthur C. Danto's concept of "artword" underlies an institutionalist theory of art (Danto [1973], [1998])

As with functionalists, historicist, cladistic and institutionalist interpretations also deny that the modern arts have an objective purpose of their own. To characterize the arts they resort to recursive procedures and deictic, extensional definitions, pointing to institutions either as historical processes or as social groups. As already stated, I will defend that an intensional definition of arts is possible.

D. Expressivism and experiencialism

Leo Tolstoy (1897) formulated the idea of art as an expression of emotions and as the language of feelings, and Curt J. Ducasse (1929) worked this idea out, defining aesthetic arts as a skilled objectification, a language of feelings. In a different sense, Collingwood's idea of art is expressiv- ist since, for him, art is an imaginary experience through which we express our emotions (Collingwood [1958]: 142). In Benedetto Croce's philosophy, aesthetic intuition grounds all other mental activity, although intuition cannot be analyzed in parts. Ordinary intuition is no different than the artwork-based intuition, although artists are able to express their intuitions. Furthermore, artworkbased intuition is created within the spectator's mind. Arts are expressive and thus proximate to human languages (Croce [1902]). The analytic philosopher Monroe Beardsley defined a work of art based on its capacity to afford an aesthetic experience $(1982,299)$, and Richard Kamber defined art as a kind of technique whose intent is to aesthetically construct interesting objects, events and designs (Kamber [1993]: 316, 319). John Dewey also located the core of the idea of art in the idea of experience and emphasized the continuity between everyday experience and the fine arts (Dewey [2005]). Wary that Dewey's idea of experience was not precise enough to explain the nature of art, Richard Shusterman recalled that Dewey himself considered the aesthetic experience to be impossible to define (Shusterman [1994]). Following Dewey, Mark Johnson has defended that all experiences, and not just those that have to do with the arts, have aesthetic dimensions and are, therefore, "aesthetic" (Johnson [2007]). In my view, Johnson and Dewey's arguments are highly compelling, but they imply that the idea of aesthetic experience does not serve as a distinctive feature to characterize the substantive arts.

Harold Osborne has argued that the idea of aesthetic experience is a vague and ambiguous notion (Osborne [1981], 10). Regarding expressivism, Osborne considers that, on the one hand, many works of art are neither more nor less expressive than many of the things we do or create and, on the other hand, there are many things that express and evoke emotions that we never would classify as works of art (Osborne [1981]: 9).

\section{E. Formalism}

Under the label of formalism, I refer to a group of authors postulating that everything nec- 
essary to understanding a work of art is within itself and, specifically, in its forms, its elements and its relationships in space and time. The issues relating to the author, viewers and historical, cultural and social contexts are secondary. Eduard Hanslick found that music has no content external to itself because it is only «tonally moving forms» (Hanslick [1986]: 29). Similarly, Clive Bell defined the essence of art as "significant form", arguing that in painting the only relevant things are the relationships and harmonies of lines and colors (Bell 1913). Clement Greenberg defined painting as a combination of «flatness, pigment and shape» (Greenberg [1986]: 86-87).

In the 20th century, the stream of art critics grouped under the label of "New Criticism" shared this conception about the disinterested nature of art and advocated for a pure, autonomous art freed from any purpose and any external influence. Artists such as the writer and painter Stanislav I. Witkiewicz and the sculptor August Zamoyski formulated a formalist theory of art (Witkiewicz [1992], Zamoyski [1975]).

Arthur Danto has been one of the most incisive critics of formalism. For Danto, the aesthetic value of an artwork depends largely on the context and, therefore, form alone does not make a work of art. Marcel Duchamp's readymades and Warhol's Brillo Boxes are examples of "mere things" that, introduced in a specific context, may constitute artworks (Danto [1973], [1998]). It is impossible for Walton to correctly adjudge an artwork in the correct categories if we do not know anything about its origins or its historical context since aesthetic properties do not only depend on shapes, colors or rhythms (Walton 1970). Conversely, in contexts far from the substantive arts, engineers and illustrators themselves make artifacts implying forms (Osborne [1981]: 9).

\section{F. Metaphysical theories}

Metaphysical theories about art, in which the ideal of beauty pursued by the arts was considered to be of divine origin, were prevalent in Antiquity and the Middle Ages. Such is the case of the philosophy of Plotinus ( $3^{\text {rd }}$ century CE), with his idea of beauty as divine essence and the imitative and emanative nature of arts. In the late $5^{\text {th }}$ and early $6^{\text {th }}$ century CE, Pseudo-Dionysios posited that truth and beauty coincide and are the cause of anything beautiful that exists. Thomas Aquinas explicitly asserted that the source of all beauty is God and derived the primary standards of beauty (actuality, radiance, proportion and integrity) from the mystery of the Trinity.

In the Renaissance, Michelangelo believed that visible beauty was the path by which the soul reached immortal Beauty, which is the reflection of God himself since the source of all beauty is divine.

Novalis conceived of art as the vision of God in Nature, and Schopenhauer elaborated a philosophy of music in which the arts were pure forms since they express no specific passion, but rather their general forms. Schiller defined beauty as freedom and autonomy in appearance and deemed freedom as something noumenal. In this vein, Hegel stated that the distinctive function of the arts is to provide a sensuous, individual manifestation of the freedom of absolute spirit. Hegel's philosophy of art constitutes the first sub-section of the third part of his philosophy of spirit, which is devoted to the absolute spirit (the other sub-sections being about religion and philosophy). Art is the lowest phase in the development of the absolute spirit: in an ascendant trajectory, the absolute spirit reaches its self-understanding and spiritual freedom through figurative objects in the arts, through images of faith in religion and through pure concepts in philosophy. Far removed from Hegelian idealism, in the philosophy of George W. Bertram, the characterization of the arts as "a practice of freedom" is enigmatic, since such "freedom" seems to reside in the noumenal background of the artist's will (Bertram [2019]: ch. 4).

Étienne Souriau compared the artist to Leibniz's God, who chooses from among all possible worlds to create a concrete and singular work the existence of which is sufficient for itself and constitutes its own purpose (Souriau [1947]: 50; 56). The arts constitute the human experience of 
God's "ontogonical" activity since the sculptor, the painter, the poet and the musician perform a task of divine creation (Souriau [1947]: 62-64). This not being sufficient, Souriau affirms that the arts, through the sensitive qualia of certain physical bodies, lead us towards an impression of transcendence (Souriau [1947]: 96). In the same vein, Martin Heidegger defined art as "bringing-into being", even though such "being" will never be completely revealed (Heidegger [2008])

Another example of a metaphysical theory of art is Ayn Rand's theory whereby art is the recreation or concretization, in an aesthetic microcosm, of the author's metaphysical value-judgments, the expression and emotional resonance of a "sense of life" that in turn defines as "a pre-conceptual equivalent of metaphysics» (Rand [1975]: 25).

\section{G. Eclecticism}

The definition of art put forward by Wladyslaw Tatarkiewicz may serve as an illustration of a disjunctive definition. For Tatarkiewicz, «art is a conscious human activity of either reproducing things, or constructing forms, or expressing experiences if the product of this reproduction, construction, or expression is capable of evoking delight, or emotion, or shock» (Tatarkiewicz [1971]: 150). The disjunctive structure of his formula is evident: either imitation, or construction or expression.

Berys Gaut (Gaut [2000], [2005]) held that art cannot be defined, since the concept of art is a "cluster concept", and put forward ten criteria counting towards an object's being deemed art:

(i) possessing positive aesthetic qualities [...]; (ii) being expressive of emotion; (iii) being intellectually challenging; (iv) being formally complex and coherent; (v) having a capacity to convey complex meanings; (vi) exhibiting an individual point of view; (vii) being an exercise of creative imagination; (viii) being an artifact or performance that is the product of a high degree of skill; (ix) belonging to an established artistic form; and $(x)$ being the product of an intention to make a work of art. (Gaut [2005]: 274)
More recently, Andreev and Kuznetsova highlighted the main components of art as a complex conceptual system. The aesthetic attitude includes the following:

spiritual specificity; semiotic trait; a system of features associated with usual forms of the social organization of artistic culture; the system of psychological characteristics (art as a sphere of personal perception, art as figurative thinking); nature of activity in art (art as a fundamentally innovative, non-algorithmic activity); and, finally, a technical attribute, the tendency to reduce art to a fixed, traditional set of techniques: pictorial, sculptural, technique of organizing verbal texts, etc. (Andreev and Kuznetsova [2019]: 72).

In my view, the dichotomy between the "single criterion" and the cluster account is false. The characterization based on genus and difference always makes use of a plurality of criteria, most of which are generic (such as criteria I-VIII in Gaut's cluster). I do not deny that Gaut's ten criteria can be predicated on the arts, but, except for IX and $\mathrm{X}$, they are all generic. Irrespective, the disjunctive definitions imply the recognition of the lack of unity in the concept of art, of its "equivocity". This theory borders on the aforementioned skepticism. In the second section, I will put forward an intensional definition of substantive arts that challenges this equivocity; if this proposal is successful, the limits of cluster theories can be better appreciated.

H. Contextualism

Christy M. Uidhir and P.D. Magnus compare the concept of art with the species concept in biology: just as there are various concepts (phenotypic, biological, taxonomic, phylogenetics), they propose the formulation of various art concepts, each serving different purposes and useful in specific contexts. Specifically, they put forward four concepts of art:

Historical art: Those artifacts emerging from, belonging to, embedded in, art-historical traditions or narratives [...], productive for historical inquiries.

Conventional art: Those artifacts recognized, accepted, targeted, governed by artworld conven- 
tions, institutions, and practices [...], productive for sociological and anthropological inquiries (as well as for legal and economic issues).

Aesthetic art: Those artifacts satisfying some aesthetic function; for example, affording some aesthetic attitude, experience, interest, value [...], productive for value inquiry and certain cognitive inquiries involving perception.

Communicative art: Those artifacts that are (act as) vehicles for the communication of certain contents; "for example, representational, semantic, or expressive content [...], productive for certain cognitive inquiries involving learning and emotions, as well as for moral evaluation.» (Uidhir and Magnus [2011]: 91-92). As with the definitions constructed using the disjunction of features, the disjunction of concepts is proof of the inexistence of a univocal concept. In previous paragraphs, I have already made some considerations about the scope of institutional, historical, and aesthetic definitions.

As regards the aesthetics of hermeneutics (Adorno [1970], Gadamer [1986]), it is widely accepted that it is not directly focused either on categorizing the nature of art or on proposing a concept of art; rather, it looks to deepen the contemplation of specific works for the sake of phenomenological engagement.

\section{THE SUBSTANTIVE ARTS AS A VARIETY OF TECHNIQUES}

2.1. All techniques and technologies follow objective aims. The distinction between objective and subjective aims

In this section, I assume that we approximately know the extension of the set of substantive arts and put forward an intensional definition of the substantive arts that bears the classic format of the generus proximus and the specific or distinctive difference. I defend that the substantive arts are a product of human doing and making and, therefore, belong to the genus of techniques (in which I include technologies). Following Aristotle's philosophy, I characterize the techniques as human practices involving a violent transforma- tion of the environment in order to accomplish specific purposes (Metaphysics 1033a ff., Nicomachean Ethics 1140a ff., Physics 192b ff.). The trait that makes it possible to distinguish a specific technique from others is always the objective aim pursued: medical techniques seek to cure the infirm, the goal of aeronautical techniques is to transport air cargo, the military techniques aim to win wars, and so on. In this paper, I hold that the substantive arts also have purposes and that the feature that enables them to be distinguished from the other techniques is precisely the objective aim that they pursue. Irrespective, I retain the label "substantive arts" since I am interested in underlining that those arts are not adjective arts. Even though they organize themselves based on aims, those aims are not external to themselves, as psychological, political, religious, military, social, economic, entertainment and other purposes are. Rather, it is my view that the fine arts can be deemed "substantive" since they have their very specific aims. My proposal is directly opposed to theories positing that arts have no definite purpose (that are "purposiveless"), running from Kant to Dipert (Kant [1790]: $\$ 44$; Dipert [1993]: 187).

When talking about aims, the distinction must be made between objective aims (finis operis) and subjective aims (finis operantis). This distinction appears explicitly formulated in Aquinas and in scholasticism. In Aquinas, the finis operis (translated as the aim of the action performed) is also called the "natural aim" and is the ultimate inherent end or goal of human action or output, it is the inner constructive aim. Any act or output always entails a finis operis. The finis operantis (translated as the aim of the moral agent) is also called the "willing aim" and is the subjective motive, purpose or willing intention of a human agent in acting. Scholastics applied this distinction to the study of human moral actions and concluded that bad subjective motives cannot change a good finis operis, as in the case of the person who gives money to the poor in search of vainglory. Conversely, good subjective motives cannot change a bad finis operis, as in the case 
of compassion-based euthanasia, since God alone can dispose of human lives.

When referring to a historical institution such as modern substantive art, it seems reasonable to suspect that, if that institution has stayed alive for several centuries, it must have some objective aims (finis operis), some objective interests that are above the will of certain individual subjects. Additionally, if substantive arts can be extensionally differentiated from other proximate institutions (techniques, crafts, decoration, science, philosophy), it seems possible to hypothesize that they should have certain distinctive objective aims. In my view, the idea of "proper function", proposed by Ruth G. Millikan (1987) and applied by Beth Preston to human-made artifacts (1998: 237-38), refers mainly to these distinctive finis operis. Anthropological and historical functionalism is a methodology based on the assumption that there cannot be durable human institution separated from objective aims. Should those aims disappear, the institution may be maintained by inertia for a certain time but, if it is not co-opted for other aims, it will tend to become a survival of mere archaeological interest, similarly to vestigial organs in biological evolution. Once the particular aims of the arts disappear as they existed in their adjective moment (religious, military, political aims, etc.), those arts now conceived of as substantive are seen in the need to co-opt new specific aims.

In this paper, insofar as I propose a specific finis operis for the substantive arts, I do not mean to say that this purpose excludes the other subjective aims, which may continue to be present: the artist very often needs to sell his work to live, and whoever finances him pursues other ends. However, this does not exclude the existence of distinctive or characteristic objective aims in the substantive arts, even though these distinctive purposes may occur in the context of and even through subjective ends. The finis operis may exist without the artist being distinctly conscious of it and without being able to express it in words.
2.2. Proposal for a distinctive intensional criterion of the substantive arts

The demarcation criterion that I put forward to differentiate what we call techniques and technologies from what we call substantive arts is as follows: substantive works of art always have analog contents with respect to other configurations and processes of reality, and these analogies always imply certain objective exploratory or analytical purposes. The substantive arts take their forms from the real world, from the categories of being (the categories of the natural sciences) and of doing and making (the categories of poiesis and human praxis). In the substantive arts, the analogy can affect either the work of art as a whole or its formal parts. This proposal entails a recognition that the essence of the substantive arts is ultimately cognitive, be it exploratory or analytical.

The theory put forward here makes use of the theory of analogy formulated by Alvargonzález (Alvargonzález [2020]) whereby the distinctive characteristics of any analogy are as follows:

1. There must be a certain asymmetry between the analogues. This asymmetry means that analogies can have various purposes depending on the directionality of the relationship: analogies aim at extrapolation or exploration when moving from a familiar source to a relatively unknown target; their purpose is to analyze reality when they make use of specific characteristics of an invented analogue, partially known, to shed light on the real source.

In an "extrapolative" analogy, the analogy starts from the most familiar source to the least known target. In the 19th century, physicists drew an analogy between the relatively well-known flow of a liquid and the unfamiliar flow of an electric current, to explore the structure of the latter. Scientists did not know exactly what an electric current was, but they imagined it as liquid flow, such that voltage was aligned with flow pressure. In the common law system, the familiar prior cases are frequently used in deciding the new ones. 
The function of an analogy is deemed "analytical" when the less familiar part of the analogy is used to identify and analyze the relevant constituents of a familiar domain since the former is easier to manipulate or to understand. The experimentation with scale model planes in wind tunnels or the maps of a given terrain may serve as illustrations of analogies done with an analytical purpose.

2. The relationship between analogues must be on the same level: either it goes from the particular to the particular or goes from the general to the general. The substantive arts do not establish general or universal principles or theorems since they are concrete products of human doing. Since the analogues always have to be at the same level of generality, it will be necessary to consider that the works of substantive art are particular constructions that present a specific analogy with other particular constructions or situations occurring outside these arts.

3. Analogues can be relationships, operations or terms. The analogy between the map and the terrain, like the analogy of realistic painting, is mainly an analogy of terms and relations, while the analogy between the flight simulator and the real airplane also implies an analogy of operations, as also happens in the analogy of the theater or the cinema regarding real life.

Leonardo da Vinci indirectly advocated for the analytical function of the arts insofar as he asserted that the purpose of sculpture and painting was none other than "knowing how to see". Works of art that are allegorical such as a portrait, sculpture, painted landscape or literary work always involve an analysis of the reality to which they refer. Frequent is the argument that painting supposes a level of analysis of painted reality much higher than that of photography, without prejudice to the fact that the latter may, in certain aspects, be more precise. Connections of external reality to art can include human actions and psychological processes. I defend that the anti-referentialist ideology accompanying conceptual art, with its idea that works of art are self-referential and its rejection of external associative connections, is purely intentional since concepts are also constructions made in the reality external to the arts.

In their extrapolative or exploratory role, artists start with specific real-world configurations, whether natural or human, and attempt to explore new compositions of parts and morphologies. In this task, they need not adhere to any special constraints, beyond those set by the material determinants of their art (the canvas in painting, gravity and the conditions of static balance in architecture and sculpture, and tonality in music). This exploratory sense stands out when it is affirmed that works of substantive art open new worlds (or universes, as is sometimes said). As already stated, works of art cannot be segregated from the rest of existing realities as separate, self-referential "worlds" or "universes", and this designation ("worlds", "universes") should be understood as a hyperbolic way of referring to the exploratory function of the arts.

The exploratory and analytical functions of the arts also make it possible to provide positive content to the demand for novel works of art, since the mere repetition of works based on traditional norms means that these functions are lost.

The argument that substantive works of art, with their analogical structure with respect to other parts of reality, fulfill an analytical or exploratory objective aim does not imply the reciprocal argument that all analogy is a substantive work of art. The use of analogies is frequent in techniques, in technologies, in the sciences, in philosophy, in law, in religions, in ethical, political and moral practice, in rhetoric, in war and in many other contexts (Alvargonzález [2020]). In such contexts, the exploratory and analytical purposes of analogies serve other aims: the aim of the technical artifact, the purpose of warfare, etc.

Artifacts and performances that are substantive art involve analogies with other parts of reality that lie outside the artwork. This is always so since no artwork is completely self-referential. As already stated, following functionalism, I suppose that there can be no enduring, specific human 
institution without objective finality (finis operis). Substantive works of art lack an immediate practical purpose in everyday life (and the finis operantis of the artists are not distinctive of the arts), but, insofar as they bear an analogical component, they must consequently retain the objective purposes typical of analogies. Insofar as we have already stripped all possible practical purposes and made them autonomous and free of practical commitments, they still have the objective purpose (finis operis) of being analogies since that purpose cannot be shed (they would only lose it if they were transcendent works made by God outside the world).

Substantive works of art are realities of human etiology. Not having to fulfill an immediate practical purpose and bearing an exclusively objective exploratory or analytical function, the activity of the arts is constrained by reality to a much lesser extent than in the rest of the techniques and technologies. Accordingly, the formal parts of the work of art can be chosen, varied and composed with a great deal of freedom. Thus, works of art conform a "depicted reality" that is always a function of reality, just as a dream relates to wakefulness. In this "depicted world" (be it pictorial, sculptural, narrative or cinematographic), the agent does not operate on reality: the depicted lion - sculpted, narrated - does not bite. It is a puppet handled by the author, and the depicted processes do not have efficient causality: depicted fire does not burn, pistols in cinema do not kill and a tempest in music does not drench.

At any rate, although this "depicted world" is a sui generis, weak mode of reality, this does not mean that it can also be the cause of real processes. Such is the case of legal fiction, fake news and counterfeits such as the famous Donation of Constantine. Parallelly, works of art, even if they are fiction, can have effects, such as the propaganda effects in Guernica and Battleship Potemkin.

In any case, the characteristic that works of art (portraits, sculptures, novels, etc.) are fictions is not a distinctive feature since it does not imply that all fictions are artistic fictions. There are also fictions in the sciences: Maxwell's classi- fying demon and Laplace's demon. For materialist philosophy, the gods in the Egyptian, Greek and Roman pantheon are fictional entities, but they are not constructions whose essence is a substantive art. Those fictions pursue other aims, such as the construction of scientific theorems and principles, and the operation of the States.

2.3. The difference between the theory of analogy and other theories of art

The aforementioned theory of analogy draws away from the theory that puts the essence of art in the imitation of the works of nature or God. Firstly, it states that the substantive arts occur in continuity with other highly heterogeneous techniques and technologies the nature of which is not always imitative. Secondly, analogy is not imitation, but rather a reasoned comparison of configurations and processes used in various contexts to explore new territories and analyze reality (Alvargonzález [2020]). Thirdly, the analogies built by the substantive arts do not only take entities in nature (the categories of being) as analogues, but also the things and processes made by humans categories that we could call anthropic.

The proposed theory acknowledges the presence of positive and negative aesthetic values in the arts, but those same values can be present as constructed values in other human techniques. Furthermore, as I have already said, we discern those values as predicated values in the works of nature.

The proposed theory on substantive arts seeks to understand the distinctive features of the autonomous arts, but can be retrospectively applied to understanding the artistic content of the adjective arts prior to the $18^{\text {th }}$ century. At no time do I deny the phylogenetic relationships of works of art of any historical moment with their predecessors. Rather, this empirical, historical manner of defining a work of art is purely indicative, deictic and extensional, even though it can be very useful in many contexts.

The philosophy of the substantive arts put forward herein is also wholly removed from subjec- 
tivism since it assumes that works of art are made from things that are outside and that the work of art itself is an intersubjective, external object or performance. Arts are not conceived of as communicative devices, as varieties of languages the function of which is representational or expressive, such as systems of communication (Dilworth [2005]). Countering Ayn Rand ([1975]: 25), even though art inevitably involves the viewer, the arts are not sufficiently defined as an act of contemplation, since many things and processes, both natural and artificial, that are not works of art are also contemplated.

Also running counter to formalism, the artanalogy theory assumes that works of art are not self-referential for two reasons: one, since they necessarily imply reference to the world outside the artwork to which they are genealogically and analogically connected, and two, since they cannot be understood apart from the anthropic, pursued objective aims and, therefore, apart from the author and spectators. Following Gadamer, the nature of works of art is interrogative and appellative, and their contents could be partially enigmatic and open to interpretation (Gadamer [1986]).

The theory presented also lies far from Ayn Rand's philosophy, which considers the work of art as an aesthetic microcosm representing, recreating or concretizing a metaphysical view (Rand [1975]: $20,25)$. Rather, the artist's metaphysical valuejudgments may be reflected in certain works of art, but they are not a distinctive and necessary essential content of the arts, for there are many works of art in which such contents are not present.

George W. Bertram defined arts as rational, human, self-determined, unassured practices embedded in tradition and related to an open future (Bertram [2019]: chp.4). Undoubtedly, substantive arts are rational, open practices embedded in tradition, but it is not as clear that they are "self-determined practices", since they have to be embedded in specific material conditions (for example, they depend on the state of techniques and technologies at each historical moment). In any case, arts share the characteristic of being rational, open, human practices embedded in tradition with many other non-artistic activities, such as political, economic, technical, technological and scientific activities, among others. Thus, Bertram's criteria are not distinctive to substantive arts. The criterion proposed by Alva Noë, who considers that artworks' main aims are confrontation, intervention, subversion and reorganization, is not distinctive either, although it may be constitutive (Noë [2015]: 29). Again, it can be argued that political activity can meet all of those purposes without being considered a substantive art. Noë puts forward certain similarities between the arts and philosophy (as «reorganizational practices») but he does not establish distinctive features to understand their differences. On the contrary, his characterization of artworks as strange tools to study ourselves and to investigate what makes us human (Noë [2015]: 30; 101) is excessively restrictive and anthropocentric since it must be taken into account the existence of artworks that have no direct anthropic reference, analogy or meaning, and contribute to investigate things and processes other than ourselves.

\section{SOME COROLLARIES OF THE PROPOSED THEORY}

3.1. On the uselessness of the theory about the essence of the arts

Making or commenting on a work of art does not require a proportionate aesthetic theory about what art is. Knowledge of the objective aims of the arts can be completely irrelevant and even detrimental to the artist and the critic. Artists whose finis operantis are the inspiration of God or the ascent to the Absolute Spirit through their art may be more motivated for their work than those possessing a non-metaphysical philosophy of art. Critics skeptical about the possibility of defining art can make many interesting considerations about a particular work of art while the philosophy of art I have defended here could inhibit them from making many of those insightful comments. 
3.2. If the arts are technical, then it is worth drawing distinctions between the arts of poiesis and the arts of praxis

If we take into account the distinction between techniques of praxis (agere) and poiesis (facere), we could also speak by extension of practical arts and poietic or productive arts. There are substantive arts requiring the actual execution of a process by one or more interpreters, as in theater, music and dance, while there are other arts that give rise to a product that separates itself from its possible interpreters, as in painting, sculpture, architecture and literature. Furthermore, this criterion shows us the internal connection between the substantive arts and the servile arts or the earlier adjective arts. Slaves and servants cultivated the servile arts by developing technical skills, both in the realm of praxis and poiesis. Free men cultivated the liberal arts so as to become wise and virtuous. The substantive arts are genetically connected with the servile arts and techniques (painting, sculpture, architecture, music, dance and theater), for no one considers a wise and virtuous man to be a work of substantive art. Servile arts were also adjective arts since they served certain external purposes (religious, political, military, social, economic, etc.).

3.3. If the arts are techniques, then they involve various degrees of destruction and reconstruction of reality

The techniques can be classified based on the degree of destruction and violence that they produce in reality, which ranges from absolute destruction (hunting, war) to the mere harnessing of natural processes (a sailing ship, a wind power station) (Bueno [2000b]).

Works of art can always be broken into formal parts such that there is no abstract art in the strict sense. Even the so-called abstract works, where the degree of deconstruction is maximal, cannot be made without forms, even though these forms are parts of the result of the destruction of the real at various scales, and even if these formal parts are strangely combined. All arts suppose the analogy, more or less recombined and varied, of earlier geometric, biological, technical, technological and other forms.

Irrespective, it is interesting to note that there are arts that do not admit the variety of "abstract art”. Relatively speaking, sculpture, painting, music and dance may lose references to specific morphologies external to the artwork and may lead to abstract sculpture, painting and (nonvocal) music. Literature, theater, vocal music and cinema cannot reach this disconnection. The function of the works of abstract art will have to be understood to a greater extent as an exploratory function such that the substantive work of art appears as a construction that invites us to explore it, as also happens so often with the abstract structures in the formal sciences that lack any application in other areas.

3.4. The analogy can affect terms, relationships, and operations: a reinterpretation of Lessing's criterion

In Laocoon, Lessing classified the arts based on the role that time plays. There are certain exclusively static arts (plastic arts, especially painting) in which time does not play a major role since it is about perceiving a fixed image. On the contrary, in other arts (singularly, poetry and theater) the succession of the parts of the work is a constituent part thereof: they are arts that have to manage time and, therefore, are somehow "narrative arts". In Laocoon, he refers to poetry, but it seems that the proposed criterion would put music, dance and cinema together with poetry and not painting (Lessing [1762]: 66).

Lessing's criterion relates to the procedural nature of the work of art. When the process of its reception is governed only by the viewer, the situation is different than when that process is narratively guided by the artist. In my view, the fundamentals of Lessing's distinction are as follows. In painting and sculpture, the understanding of analogies only requires the consideration of the similarities between terms and relations. In literature, dance and music, it is essential to also keep in mind the similarities between the operations of the subjects involved (musicians, dancers, narra- 
tors, dramatic characters) since those arts include the deployment of a narrative time.

\subsection{The psychagogical function of the processual arts}

In certain arts, the artist leads the viewer to see, hear and read at all times what the author imposes. The spectator or reader agrees to be guided, to be exposed at all times to the stimuli that the author wants, to be led by the hand. The author manages the audience's emotions, awakens and dulls their desires and alters their feelings and passions, building a narration given in time. The author acts a psychagogist, a conductor or guider of souls.

The question that should be discussed is whether or not the psychagogical function of the arts turns these arts into servile arts at the service of that sentimental drive. On the contrary, it can be defended that they remain substantive arts attempting to explore subjective and social contents so as to carry out this liberating catharsis, which allows us to take some distance from that psychological and social world.

The psychagogical function of the arts is a specification of the aforementioned analytical and exploratory functions where the understanding of specific analogies requires not only considering the similarities between terms and relations but also between the operations of the involved subjects. In painting and sculpture, we mostly have terms and relationships and, consequently, their psychagogical effect is comparatively weak, whereas in the narrative arts we have to take into account the analogy of operations and their unfolding in time. Accordingly, in those processual arts, the psychagogical effect is inescapable.

\section{REFERENCES}

Adajian, T., 2003: On the Cluster Account of Art,

"British Journal of Aesthetics", 43, pp. 379-385. Adorno, T.W., 1970: Aesthetic Theory, transl. by R. Hullot-Kentor, University of Minnesota Press, Minneapolis, 1997
Alvargonzález, D., 2020: Proposal of a classification of analogies, "Informal Logic", 40 (1), pp. 109137.

Andreev, A.L., Kuznetsova, T.V., 2019: How to define art?, "Voprosy Filosofii", 8, pp. 72-79.

Batteux, C. 1746: The Fine Arts Reduced to a Single Principle, Oxford University Press, Oxford, 2015.

Beardsley, M. C., 1982: The Aesthetic Point of View, Cornell University Press, Ithaca (NY).

Bell, C. 1913: Art, Oxford University Press, Oxford, 1987.

Bertram, G. W., 2019: Art as Human Practice. An Aesthetics, Bloomsbury Academic, London.

Bueno, G., 2000a: Estética y filosofía del arte, in Pelayo G. (ed.) Diccionario filosófico, pp. 649677, Pentalfa, Oviedo.

Bueno, G. 2000b: Televisión: apariencia y verdad, Gedisa, Barcelona.

Carney, J. D., 1994: Defining Art Externally, "The British Journal of Aesthetics", 34, pp. 114-23.

Carrol, N., 1988: Art, practice, and narrative, "Aesthetics and the History of Arts", 71 (2), pp. 140-156.

Carrol, N., 1997: Danto's new definition of art and the problem of art theories, "British Journal of Aesthetics", 37 (4), pp. 386-392.

Clowney, D., 2011: Definitions of art and fine art's historical origins, "Journal of Aesthetics and Art Criticism”, 69 (3), pp. 309-320.

Collingwood, R. G., 1958: Principles of Art, Oxford University Press, Oxford.

Croce, B., 1902: Aesthetics as Science of Expression and General Linguistic, Macmillan Company, New York, 1909.

Danto, A. C., 1973: Artworks and Real Things, “Theoria", 39, pp. 1-17.

Danto, A. C., 1998: The end of the art: A philosophical defense, "History and Theory", 37 (4), pp. 127-143.

Davies, S., 1997: First art and art's definition. "Southern Journal of Philosophy”, 35 (1), pp. 19-34.

Davies, S., 2004: The cluster theory of art, "British Journal of Aesthetics", 44 (3), pp. 297-300.

Davies, S., 2010: Philosophical Perspectives on Art, Oxford University Press, Oxford. 
Davies, S., 2015: Defining art and artworks, "Journal of Aesthetics and Arts Criticism”, 73 (4), pp. 375-384.

Dewey, J., 1932: Art as Experience, Perigee, New York, 2005.

Dickie, G., 1974: Art and the Aesthetic: An Institutional Analysis, Cornell University Press, Ithaca (NY).

Dipert, R. R., 1993: Artifacts, Art Works, and Agency, Temple University Press, Philadelphia (PA).

Dissanayake, E., 1992: Homo Aestheticus: Were Art Comes From and Why, Free Press, New York.

Ducasse, C. J., 1929: The Philosophy of Art, The Dial Press, New York.

Eibl-Eibesfeldt, I., 1988: The Biological Foundations of Aesthetics, in Rentschler, I., Herzberger, B. and Epstein, D. (eds.) Beauty and the Brain: Biological Aspects of Aesthetics, Birkhäuser, Basel, Switzerland, pp. 29-68.

Fokt, S., 2014: The Cluster Account of Art: A Historical Dilemma, "Contemporary Aesthetics", 12 (1), pp. 1-14.

Fokt, S., 2017: The cultural definition of art, "Metaphilosophy”, 48 (4), pp. 404-429.

Gaut, B., 2000: "Art" as a Cluster Concept, in Carroll, N. (ed.), Theories of Art Today, University of Wisconsin Press, Madison (WI), pp. 25-44.

Gaut, B., 2005: The Cluster Account of Art Defended, "The British Journal of Aesthetics", 45, pp. 273-88.

Gadamer, H. G.. 1967 and 1977: The relevance of the beautiful, in The Relevance of the Beautiful and other Essays, transl. by N. Walker, Cambridge University Press, Cambridge, 1986.

Goodman, N., 1968: Languages of Art: An Approach to a General Theory of Symbols, Bobbs-Merrill, Indianapolis (IN).

Goodman, N., 1978: Ways of Worldmaking, Hackett Publishing Company, Indianapolis (IN).

Goodman, N., Elgin, C. Z., 1988: Reconceptions in Philosophy and Other Arts and Sciences, Routledge, London.

Greenberg, C. 1986: The Collected Essays and Criticism, University of Chicago Press, Chicago (IL).
Hanslick, E. 1986: On the Musically Beautiful, Hackett Publishing Co., Indianapolis (IN).

Hegel, G.W.F., 1818-1829: Aesthetics. Lectures on Fine Art, transl. by T.M. Knox, 2 vols., Clarendon Press, Oxford, 1975.

Heidegger, M., 1935-36: The origin of the work of art, in Basic Writings, transl. by D. F. Krell, Harper, New York, 2008, pp. 139-212.

Johnson, M., 2007: The Meaning of the Body: Aesthetics of Human Understanding, University of Chicago Press, Chicago (IL).

Kamber, R., 1993: A Modest Proposal for Defining a Work of Art, "The British Journal of Aesthetics", 33, pp. 313-20.

Kant, I., 1790: Critique of the Power of Judgement, Cambridge University Press, Cambridge, 2000.

Kristeller, P. O., 1951: The Modern System of the Arts: A Study in the History of Aesthetics, I., "Journal of the History of Ideas", 12 (4), pp. 496-527.

Kristeller, P. O., 1952: The Modern System of the Arts: A Study in the History of Aesthetics, II., "Journal of the History of Ideas", 13 (1), pp. 17-46.

Levinson, J., 1979: Defining Art Historically, "The British Journal of Aesthetics", 19, pp. 232-250.

Levinson, J., 1989: Refining art historically, "Journal of Aesthetics and Art Criticism”, 47 (1), pp. 21-33.

Levinson, J., 1993: Extending Art Historically, "Journal of Aesthetics and Art Criticism", 51, pp. 411-423.

Levinson, J. 2002: The Irreductible Historicality of the Concept of Art, "British Journal of Aesthetics”, 42 (4), pp. 367-379.

Lessing, G. E., 1762-66: Laocoon: or, The Limits of Poetry and Painting, Ridgeway, London, 1836.

Mattick, P., 2003: Art in Its Time: Theories and Practices of Modern Aesthetics, Routledge, London.

Miller, G., 2000: The Mating Mind: How Sexual Choice Shaped the Evolution of Human Nature, Doubleday, New York.

Millikan, R. G., 1987: Language, Thought, and other Biological Categories: New foundations for Realism, MIT Press, Cambridge (MA) 
Murphy, M., 2018: Pure art, pure desire: Changing definitions of l'art pour l'art from Kant to Gautier, "Studies in Romanticism", 47 (2), pp. 147160.

Noë, A., 2015: Strange Tools: Art and Human Nature, Hill and Wang, New York.

Novalis (Georg Friedrich Philipp von Hardenberg), 1802-1846: "Logological Fragments I". In Philosophical Writings, ed. and transl. by M. M. Stoljar, Suny Press, Albany (NY), 1997.

Novalis (Georg Friedrich Philipp von Hardenberg), 1802-1846: Notes for a Romantic Encyclopaedia (Das Allgemeine Brouillon), ed. and transl. by D. W. Wood, Suny Press, Albany (NY), 2007.

Osborne, H., 1979: Abstraction and Artifice in Twentieth-Century Art, Clarendon Press, Oxford.

Osborne, H., 1981: What is a work of art?, "The British Journal of Aesthetics", 21 (1), pp. 3-11.

Preston, B., 1998: Why Is a Wing Like a Spoon? A Pluralist Theory of Function, "The Journal of Philosophy", 95 (5), pp. 215-254.

Rand, A., 1969-1975: The Romantic Manifesto: A Philosophy of Literature, New American Library, New York.

Rosenkranz, K., 1853: Aesthetics of Ugliness, Bloomsbury Academic, London, 2015.

Schiller, F., 1795: Letters on the Aesthetic Education of Man, transl. by Snell R., Dover, Boston (MA), 2004.

Schopenhauer, A., 1819: The World as Will and Representation, transl. by R. Aquila, Pearson, New York, 2007.

Shusterman, R., 1994: Dewey on experience: Foundation or reconstruction?, "The Philosophical Forum", 26, pp. 137-148.

Souriau, E., 1947 : La correspondence des arts. Éléments d'esthetique comparée, Flammarion, Paris.

Stecker, R., 1990: The boundaries of art, "British Journal of Aesthetics", 30, pp. 266-272.

Stecker, R., 2000: Is it reasonable to attempt to define art?, in Carroll N. (ed.), Theories of Art, University of Wisconsin Press, Madison (WI), pp. 45-64.
Tatarkiewicz, W., 1971: What is art? The problem of definition today, "The British Journal of Aesthetics”, 11 (2), pp. 134-153.

Tolstoy, L., 1897: What is art?, Penguin, London, 1995.

Uidhir, C. M., Magnus, P. D., 2011: Art concept pluralism, "Metaphilosophy", 42 (1-2), pp. 83-97.

Walton, K.L., 1970: Categories of Art, “The Philosophical Review”, 79 (3), pp. 334-367.

Weitz, M., 1956: The Role of Theory in Aesthetics, "Journal of Aesthetics and Art Criticism", 15, pp. 27-35.

Wilcox, J., 1953: The beginnings of L'art pour l'art, "Journal of Aesthetics and Art Criticism", 11, pp. 360-377.

Witkiewicz, S. I., 1992: New forms in painting and the misunderstandings arising therefrom, in $\mathrm{D}$. Gerould, (ed.), The Witkiewicz Reader, Northwestern University Press, Evanston (IL).

Zamoyski, A., 1954: "Art and substance". Lecture delivered at the Philosophical International Congress. Sáo Paulo, in Zamoyski, A. (french transl.), Au-delà du formisme, Collection Slavica-Écrits sur l'art 4, Editions L’Age d'homme, Lausanne, 1975, pp. 11 -197.

Ziff, P., 1953: The Task of Defining a Work of Art, "Philosophical Review", LXII, pp. 58-78. 